\title{
Critical Reflections of College Sophomores About Preparation and Persistence During Their Freshman Year
}

\author{
Gregory V. Wolcott
}

The purpose of this study was to explore the needs and experiences of college freshmen with the hope of informing universities how to improve freshman preparation and persistence. Focusing on students at a public "metro-commuter" university, this qualitative study extends previous research on the topic. Using participatory research methodology, this study utilized dialogues to explore the critical reflections of students who have successfully completed the freshman year. This study found that during the preenrollment phase, it is critical that students and their families experience programs and services that educate students about the transition to college, increase students' commitment to the institution, and help students develop realistic expectations for college. Several factors were found to contribute to college freshman persistence including support for social and academic integration, academic engagement, fostering student development, and promoting internal locus of control. The author argues that preenrollment programs must be viewed as critical to student success, and should be mandatory and carried out utilizing current students who are trained in issues of transition. He concludes that more programs are needed throughout the first year to help students develop social support networks.

The freshman year of college in the U.S. is a definitive time of transition and development. It is a period of exploration, identity development, and broadening horizons for new students. Students embark on college with great anticipation and preconceived expectations about what the college experience will be like. Because the needs and expectations of freshman are many, institutions of higher education must be concerned with the support they offer to incoming freshmen. These students are the lifeblood of the institution and therefore are worthy of great attention.

\section{Purpose of the Study}

The purpose of this study was to explore the needs and experiences of college freshmen with the hope of informing universities how to improve freshman preparation and persistence. Focusing on students at a public, metropolitan/commuter ("metrocommuter") university, this qualitative study extends previous research on this topic. Using participatory research methodology, this study utilized dialogues to explore the critical reflections of college sophomores who have successfully completed the freshman year.

Gregory V. Wolcott (gwolcott@sjsu.edu) is the associate director for Student Involvement at San Jose State University. This article is based on research for which Dr. Wolcott received the 2006 NODA Outstanding Research Award. 
Participants were asked to reflect on the programs and services they needed from the institution prior to and during their first year, and how the institution responded to their needs. Participants also explored how the programs and services offered by the university helped them persist throughout their first year, and offered recommendations to the institution and to future incoming freshmen based on their experience. These responses may increase the likelihood of success for future students throughout the freshman year. These reflections also begin to explain the type of personal and educational experiences that support the preparation and persistence of college freshmen.

\section{Research Questions}

The following research questions guided this study:

1. What programs and services do college freshmen need to prepare for their first semester?

2. What factors lead to the persistence of college freshmen through their first year?

3. What recommendations do current students have for the institution and for future freshmen about promoting and achieving first-year success?

\section{Literature Review}

College student success is largely determined by experiences during the freshman year (Smith \& Bracken, 1993; Tinto, 1993; Upcraft \& Gardner, 1989a). Therefore, a vast amount of research focusing on the freshman year experience has been conducted (Chickering \& Reisser, 1993; Gardner, 1986; Gardner \& Hansen, 1993; Greenlaw, Anliker, \& Barker, 1997; Levitz \& Noel, 1989; Mullendore, 1998; Mullendore \& Abraham, 1993; Upcraft, 1993; Upcraft \& Gardner, 1989b; Ward-Roof \& Hatch, 2003). Studies have shown that the elements that students bring with them to college often dictate their level of satisfaction and success (Astin, 1993, 1997; Johnson, 2002; Ward-Roof, 2003). According to Astin (1997), "More than half of the variance in institutional retention rates can be attributed directly to the differences in the kinds of students who initially enroll, rather than to any differential institutional effect" (p. 648). Certain precollege factors have been found to contribute to a college student's ability to succeed. Astin (1997) found that students who were White, female, and had high grade point averages performed better than all others. In fact, a student with high grades and test scores was "more than three times more likely to complete college than those with low grades and test scores" (p. 651). In addition, students' majors also affect time to graduation. For example, students in the hard sciences, such as engineering, take longer to graduate or graduate less frequently than those in social science majors. It should be noted here that although half of the variance in retention can be attributed to student factors, the other half is caused by factors that are beyond students' control such as how the institution promotes their success.

Another factor that contributes to the success of college freshmen is status as a first- 
generation college student. According to Terenzini, Springer, Yaeger, Pascarella, and Nora (1996), first-generation college students differ from their traditional peers "in both the personal and educational characteristics they bring with them to college and in the nature of the experiences they have during their first year there" (p. 18). Finally, parents and families can be a determining factor in the success of college freshmen and if they persist throughout the first year. Murray claims that parental involvement in children's activities has changed with today's parents being more active supporters and spectators (as cited in Cawthon \& Miller, 2003).

Similarly, college student retention has been studied at great lengths since the 1970s (Astin, 1975, 1984, 1993, 1996, 1997; Johnson, 2002; Kennedy, Gordon, \& Gordon, 1995; Milem \& Berger, 1997; Sanders \& Burton, 1996; Tinto, 1975, 1987, 1993, 1997; Upcraft, 1989, 1993; Ward-Roof, 2003; Wilkie \& Redondo, 1996). The American College Testing Program (2001) reported that nearly two thirds of high school graduates now go directly into higher education, and $74.2 \%$ of college freshmen are retained after the freshman year. There are common variables that account for the variance in retention including high school grades, admissions test scores, gender, and race (Astin, 1993). In addition, "socioeconomic status, religion, hedonism, and political orientation" contribute to retention variables as well (Astin, 1993, pp. 193-194). In his benchmark study, Tinto (1993) reported that 2.4 million students entered college in 1993, but fewer than one million stayed in school after the first year. Like many findings on college freshman retention, this statistic does not reflect those students who transferred to other institutions or who took a break from their studies and eventually returned.

Also, Tinto's study focused primarily on full-time, traditional aged students who attended residential institutions. According to Astin (1997), institutions that are considered large and commuter are more at risk for lower retention rates. At these institutions, students often take longer than the traditional four years to graduate. This trend leads to a skewed illustration of the institution's retention and graduation rates because these rates are typically measured using a 4-year standard. In addition, students of color are retained at a lower rate than their White peers (Berger \& Milem, 1999; Hickok, 2006; Strage, 1999), and their graduation rates are much lower, sometimes as much as 20 percentage points (Burd, 2004). Berger and Milem's (1999) discovered that although African American students enter institutions with high levels of institutional commitment, they are less likely to perceive the institution as being supportive and therefore less likely to persist. Strage (1999) found that Asian American students had less academic and social confidence, felt like less of a leader, tended to have less internal locus of control, and felt they had an inferior rapport with instructors when compared to their Hispanic and White counterparts. These studies indicate that freshman retention is worthy of further investigation, especially at diverse, metro-commuter institutions.

Studies on college student retention are typically quantitative and examine statistics such as preenrollment factors, grade point average, course load, and academic rank. Although these statistics may be important to gauge college freshmen success at the institutional level, the studies using these statistics fail to capture student experiences, perceptions, and satisfaction. These studies either fail to collect information from 
students directly, or, for those studies that involve students, do not allow students to elaborate on their opinions in a descriptive way.

The results of quantitative studies have little meaning to freshmen because they are defined in institutional terms and lack students' perspectives and "voice" (Belenky, Clinchy, Goldberger, \& Tarule, 1986; Freire, 1993; Maguire, 1987). Astin (1997) explained the flaws in this approach to assessing freshman success: "Attempts to assess institutional performance by means of retention rates, student performance on standardized tests, and other raw outcome measures are seriously flawed because such measures fail to take into account the powerful effect of student inputs" (p. 647). What remains to be seen are the critical reflections of college sophomores about preparation and persistence during their freshman year. The present study attempted to address this issue.

The review of the literature consisted of three sections. The first section focused on the theories that relate to this study. Tinto's $(1975,1993)$ theory of student departure was appropriate for this study because it recognized that both students and the institution play a role in promoting preparation and persistence. His theory of student departure is like other college impact theories of student change in that it views persistence as primarily a function of the student's fit with the college environment. These types of theories also contend that student background characteristics before entering the institution, the institutional environment, and student involvement all have an impact on the college experience (Lewallen, 1993). Chickering and Reisser's (1993) vectors of psychosocial development, which helped a generation of professionals better understand the development of college students, was the second theoretical framework. These theorists examined how earlier psychological research could be applied to college students, creating what they called "seven vectors of development" (Chickering \& Reisser, 1993, p. xv). The vectors include a wide range of abilities such as developing identity, becoming interdependent, and managing emotions. This theory provided the researcher a base of knowledge to understand the experiences of the participants and to interpret their experiences in a larger context.

The second section of the literature review explored studies on the freshman year experience, examining how it related to students' needs prior to and during their first year. This research concentrated on the freshman transition process, orientation programming, freshman seminars, and empirical studies related to preenrollment experiences and expectations of college students.

The third section of the literature review examined empirical studies on college student retention, with a majority of the studies focused on freshmen. Many of these studies employed Tinto's $(1975,1993)$ model of student departure as a means to explain freshman persistence. Three themes were identified in the empirical studies - student inputs, internal locus of control, and student involvement-as being supportive of freshman retention and persistence. The literature review illustrated that more needs to be learned about freshman retention and persistence at a public metro-commuter institution, especially from a student and participatory research perspective. 


\section{Methodology}

This qualitative, participatory research study utilized dialogic retrospection (Kieffer, 1981 ) as a means of engaging participants in a conversation about their experiences during the first year of college. A total of six students were invited to share their thoughts and experiences in reflecting on how the institution assisted them before their first semester and during their first year. The participants were asked to copresent the findings and recommendations of the study to the Orientation Advisory Team, a group made up of deans, directors, and other administrators responsible for freshman success.

By using participatory research in this study and having the students engaged in sharing the findings, the student participants and the researcher reached "critical consciousness" (Maguire, 1987) and began to transform their own realities. The participants' experiences may help contribute to the decision-making process used by administrators who develop programs and services for freshmen. In doing so, the participants' experiences could help transform the freshman year experience for future students.

At the core of its purpose, participatory research is meant to bring about change to form a more socially just world. Park (1993) states that the goal of participatory research is "to bring about a more just society in which no groups or classes of people suffer from the deprivation of life's essentials, such as food, clothing, shelter, and health, and in which all enjoy basic human freedoms and dignity" (p. 2). Maguire (1987) states that participatory research is focused on three types of change: "development of critical consciousness of both researcher and participants; improvement of the lives of those involved in the research process; and transformation of fundamental societal structures and relationships" (p. 30). This focus on change makes participatory research different from other kinds of research.

Maguire (1987) explained that participatory research challenges traditional social science research as the only source of knowledge production. In traditional quantitative research, important social phenomena are sometimes reduced to statistics and other variables that can be controlled. Only the elite benefit from the enhanced capacity for prediction and control. "By treating people as objects to be counted, surveyed, predicted, and controlled, traditional research mirrors oppressive social conditions which cause ordinary people to relinquish their capacity to make real choices and to be cut out of meaningful decision making," according to Maguire (p. 31). Contrary to traditional research,

this alternative style of research uses a three-part process of social investigation, education and action to share the creation of social knowledge with oppressed people. Rather than merely recording observable facts, participatory research has the explicit intention of collectively investigating reality in order to transform it.

(Maguire, 1987, p. 3) 


\section{Participants and Participant Selection}

Potential participants for this study were students who were sophomores at the institution. Sophomores were chosen because they had recently completed the freshman year and therefore were able to reflect on their freshman experiences in a meaningful way. Six students were invited to participate in the study (see Table 1). Participants were selected from a cohort of approximately 2,400 freshmen who entered the university in fall 2004. A majority of these students participated in freshman orientation. There were a small number, however, that did not attend orientation but did participate in a 2-hour advising session the day before classes began in fall 2004. These students (approximately 70 total) typically have exceptional situations such as being admitted late, not having test scores, or waiting until the last minute to decide to come to the institution. One student from this group participated in the study and offered a different perspective on the freshman year experience.

Participants were asked to sign a form stating that they understood the purpose of the study and that their participation was voluntary. Students were paid a stipend of $\$ 25$ for their participation in the study. The time commitment was approximately 3 hours. This commitment included approximately 1 hour for the first dialogue, 1 hour for the second dialogue, and 1 hour in between to review the transcripts and generative themes that the researcher developed. The dialogues took place between November 2005 and February 2006. Protecting confidentiality was of utmost importance during the study.

\section{Findings}

The findings of the study are described in terms of the three research questions and the themes that emerged with each one. Many responses from participants were analyzed for content, which materialized into themes under each research question. These themes represent the voice of the participants who successfully persisted into their sophomore year. These findings are reported in Table 1.

\section{Research Question \#1: What services do college freshmen need from the institution to prepare for their first semester?}

The participants reflected on their high school experience and how well prepared they were for the transition they faced. Four of the participants felt they were well prepared by their high school in terms of having access to resources for college and being academically prepared. However, two of these four participants did not perform well academically in their first semester. One struggled with midterms but then recovered and performed fairly well. The other participant had only one course his first semester, which he failed, and went on to get all Cs in his second semester. Therefore, there was no direct link in this study between students who self-reportedly came from academically focused high schools and how well they performed during 
their freshman year. Two of the participants felt they were left to find out about college on their own. Although they succeeded in certain social aspects of college in their first year, they both struggled academically, being placed on probation, and were near the point of dropping out. These findings support Astin's (1993) premise that about half of the variance between freshman success can be attributed to individual factors students bring to college, while the other half is attributed to how they are supported by the institution.

The participants were very open about describing their feelings during their transitional period. Feelings ranged from anxiety, nervousness, and being homesick to excitement about leaving home, willingness to meet others, and a sense of belonging in their new home. In some cases, the feelings that the students had leading up to college dictated their experience with transition and precollege programs.

All of the participants discussed transition and precollege programs, and their experiences in participating in them. Research has shown that students who participate in these programs are more successful than nonparticipants (Devlin, 1996; Gardner \& Hansen, 1993; Fidler \& Hunter, 1989; Hunter, Skipper, \& Linder, 2003; Jewler, 1989; Strumpf \& Sharer, 1993; Tinto, 1993; Upcraft, 1989, 1993; Young, Backer, \& Rogers, 1989). The programs discussed included the Admitted Student Reception, ASPIRE, the Educational Opportunity Program (EOP), Housing's Frosh Start program, a mini-advising session, the Metropolitan University Scholars Experience (MUSE) freshman seminar course, and freshman orientation. The participants' experiences in these programs varied depending on their background, level of anxiety about coming to college, preparedness, and individual experiences at these programs.

Tacey is very close to her family and was quite anxious about leaving home for college. This led to a negative experience at orientation when she was separated from her mother for a portion of the program. She also did not enjoy the evening portion of the program or the advising session, which did not include parents. Venus, on the other hand, was excited about leaving home. She had a positive experience at orientation because she met others with whom she shared things in common. Venus also experienced her first cultural experience with someone from a different race at orientation, which she reported as very positive.

In some cases, the students' perceptions of their experiences at these programs were directly related to their experience with the faculty and staff involved in them. Two participants reported having negative experiences in their MUSE freshman seminar classes because they did not like the style of the professor or the course content. One participant also reported that there was very little content in the class that focused on transition issues. Another participant reported mixed feelings with MUSE, stating she did not get along with the instructor, but that she bonded with one of her classmates in that class. Another participant had a negative experience with a faculty member on the first day of classes, adding to her sense of anxiety and stress. Ralphie did not attend orientation, but instead attended a mini-advising session the day before classes began. Although he reported having a good experience at this session, he went on to experience a difficult time securing classes in his first semester. This is due to the fact 
that students register for classes at orientation. Those who do not attend must "crash" courses at the start of the semester, trying to secure a spot in the class. This approach did not work well for Ralphie, as he was only able to register for one class. This made him feel like he was "not a real student" in his first semester.

There were an equal number of positive reports of the participants' experiences with transition and precollege programs. One participant reported having a positive experience at the Admitted Student Reception because it made her feel good about being admitted to the institution. Taylor said she got well connected to faculty, staff, and students at orientation. In fact, 4 out of 5 participants who attended orientation reported a very positive experience. Taylor also discussed her initial contact with the Humanities Honors Program at orientation, and how this program assisted her throughout the first year to remain engaged. Jesse also had a good relationship with the advisers in ASPIRE, which continues to serve as a support mechanism for her.

Many of the participants shared the same sentiment about their initial feelings about attending San Jose State University. The institution was not the first choice for many of the participants, leading to resentment, negative attitudes, shame, and frustration about attending. Four participants stumbled upon SJSU as an option for college, while 2 participants are legacies, meaning their parents or siblings had attended.

Tacey and Ralphie reported that they did not recall receiving an official admission letter from the university. This led Tacey to question her decision to enroll. She and others also reported frustrations with communication from the university during her precollege experience, which contributed to anxiety and limited the possibility that she would have a positive experience at precollege programs. As noted previously by Austin (2003), early mailings and communications set the tone for how families view their relationship with the university.

Regardless of initial feelings toward the institution, all participants reported feeling much more enthused about being a student at SJSU. This change in attitude was attributed to the positive experiences they had thus far in their college careers including making friends, getting involved, living on campus, having positive interactions with faculty and staff, and giving back to the institution through on campus activities and part-time jobs. These reflections indicate the importance of the institution to provide frameworks where students can have positive experiences early on in their first semester, or what Rendon (1992) calls "validating experiences."

All of the participants reported not knowing what to expect in college. Compared to their high schools, or "sending environment" (Banning, 1989), the institution, or "receiving environment," was larger, more urban, and more diverse. This led some of the participants to experience "culture shock" and difficult transitions, which supports the findings of Banning's study. The participants developed their expectations based on several criteria including conversations with friends, what they saw on MTV, and their visits to campus during the transition process. Of all the media mentioned, attending programs on campus led to the most realistic expectations. For some participants, realistic expectations about academics were not formed until they matriculated. The participants noted how different the classes were in terms of laying out the coursework 
on the first day ("Freshman 05"), the increase in difficulty in research (Ralphie), and how difficult it was to make friends in class (Tacey, Venus). These participants would have had more realistic expectations had they been introduced to classes during a precollege program or seminar class.

\section{Research Question \#2: What factors lead to the persistence of college freshmen through their first year?}

Tinto's $(1975,1993)$ model of student persistence points to two main factors in the retention of college students: social integration and academic integration. Social integration is seen as how well the students adapt to the social atmosphere of the campus including life outside the classroom, maintaining family and peer relationships, and being involved in cocurricular activities. Academic integration is concerned with the formal education of students in the classroom and interaction with faculty. Both social and academic integration emerged as themes from the dialogues.

Several participants reported extreme parental involvement during the precollege phase. Taylor explained that her parents opened all of her mail regarding college acceptance before she saw them. Her parents often knew the result of her acceptance before she did. These findings are supported by research that the parents of college students today are highly involved in their education (Austin, 2003; Cawthon \& Miller, 2003; Murray, 1997; Ward-Roof \& Hatch, 2003).

Parents were also influential in encouraging the participants to attend college and choose SJSU. Two participants remarked that if it were not for her parents, they would have never survived the first semester of college. Several reported considering whether to drop out or not, but changed their minds after discussions and encouragement from their parents. This encouragement included supporting the student's choice of major, being supportive through phone calls and visits, and calling the university on the student's behalf. These findings are supported by research on today's college students, who are labeled by Howe and Strauss (2000) as "Millennials." Millennial students teeter between asking their parents to intervene on their behalf and demanding independence in all decisions related to the university.

An unexpected subtheme emerged regarding family support: parental support perceived as pressure. Several participants reported that they did not want to "let their parents down" or "fail in front of their family." Taylor probably experienced the most pressure due to her status as a first-generation college student. Even her extended family was up to date about her performance in college. Great expectations were placed on her to succeed and set the example for future generations.

One final subtheme that emerged in this section was that participants discovered that they needed to forge new relationships with their parents. Tacey noticed this first when she went home for winter break during her freshman year. She was forced to negotiate her new practices, such as staying up late, with her parents' rules of the house. Venus also noted that the relationship with her family changed as a result of her attending college, forcing her younger sister to help her mother more to support the family. This 
phenomenon can be compared to what Cohen (1985) calls "forging dual citizenships" in the campus community and the family of origin (as cited in Austin, 2003).

Peers were cited as a great source of support by many participants. Tacey and Taylor explained that they made many friends in the residence halls, which encouraged them during difficult times their first year. Tacey reported that having friends on campus motivated her to return to campus after spending long weekends or breaks at home. Venus also made many friends in her dorm, beginning on the first day on her floor and in the elevator. Her friends continue to be a source of support and understanding. For her, they have become like her family. In Jesse's case, friends were a negative influence. She explains that they were "discouraging" and influenced her to socialize more than study.

Another realm of peer support was expressed as being connected to student leaders on campus. Jesse connected early on with Joel, a member of the student government, who explained to her how to meet the math test requirement and remain in school. Both Taylor and Tacey emphasized how important the resident assistant staff was in the residence halls. The staff made them feel more at home and comfortable. Several participants also remarked about the student orientation staff, saying they were welcoming, friendly, impressive, and memorable. Two of the participants were so engaged by the staff that they joined the staff in their second semester.

Astin $(1975,1984)$ suggested that students are more successful when they are involved in campus life and cocurricular activities. The findings of this study support this claim. According to "Freshman 05" and Venus, their involvement in activities on campus helped them make friends quickly. Taylor talked about how her involvement on the orientation staff, in the residence halls, and in the theater department help increased her commitment to the institution. Being involved also led to personal development in some of the participants. Participants reported being more social, outgoing, talkative, better able to make friends, and more accepting of diversity as a result of being involved. Ralphie noticed a significant difference between his first and second semester as it related to his feeling of belonging on campus. The difference was due to the fact that in his first semester he took only one class and spent little time on campus, whereas in the second semester, he took a full course load, spent time between classes with friends, and often studied at the library.

Participants in the study were very complimentary about their professors and staff with whom they had interacted. Faculty and staff were described as caring about students on an academic as well as personal level, taking extra time to help outside the classroom, being encouraging, and believing in students. Taylor had one of the most positive experiences with faculty and staff, connecting with faculty in the Humanities Honors Program and theater department, and with professional staff in Orientation.

Venus and Ralphie had not made many connections to faculty and staff. Venus noted that she was still trying to overcome her cultural affiliation toward independence, while Ralphie explained he had a similar approach to interacting with faculty. Ralphie's behavior may also have been impacted by the fact that he did not attend orientation and was not introduced to many faculty and staff until his second semester. Several other 
staff interactions were mentioned as positive including those with the Learning Assistance Resource Center (LARC), Educational Opportunity Program (EOP), ASPIRE, Orientation, Student Life and Leadership, and Associated Students.

The students also reported some negative interactions with faculty and staff. Tacey's experience with advisers has already been mentioned as being negative. She also had a negative experience with a faculty member on her first day of classes. However, it doesn't appear that the faculty member was particularly negative; rather, the situation of signing up for the wrong class cast him in a negative light. Two participants in the study reported having negative interactions with their MUSE professors, stating the teacher's style to be challenging. Taylor also described faculty as being too outspoken about their personal views, and alienating some students and even impacting their grades if they did not agree. Jesse also had a discouraging interaction with a math professor who told her that she would never pass the class, and that she should start looking into transferring to a community college. Jesse also had a negative experience with the university police department, which broke up a party and used excessive force with African American students.

Academic engagement emerged as a subtheme as participants discussed if they enjoyed their coursework and were being challenged academically. Tacey reported feeling bored academically during her first semester, but now being challenged by course work. It should be noted that Tacey felt well-prepared academically for college. Taylor, also felt academically prepared, and believed she was engaged by her coursework and professors in the humanities and theater departments. Although Ralphie came from an affluent high school, he did not indicate he felt academically well-prepared, and did not perform well during his first year.

Research has shown that the attributes students bring to college have a great impact on their persistence rates (Astin, 1993, 1997; Johnson, 2002; Tinto, 1993; Ward-Roof, 2003). Although "Freshman 05" reported that his high school had an "academic culture," he struggled at first to adapt to course work. Venus and Jesse did not feel academically prepared for college, and in fact struggled to the point of being placed on academic probation. It is interesting to note that these participants are students of color and share this common experience, despite having different academic preparation for college.

Chickering and Reisser (1993) identified seven "vectors of development" for college students (p. 3). These vectors include developing competence, managing emotions, moving through autonomy toward interdependence, developing mature interpersonal relationships, establishing identity, developing purpose, and developing integrity. The participants described several reflections that are relevant to the vectors.

Three participants discussed how they had begun to develop competence in their belief system. They cited changing their beliefs in terms of viewing others, affirming their political affiliations, learning about different family structures, and learning to manage time wisely. Establishing identity was discussed by several participants, but most directly by Taylor and Tacey. They had somewhat divergent views on what it meant to be in college and to develop one's identity. Tacey said, "College is a time for you to figure out who everybody else knows you are." Taylor stated, "College is a time 
for you to be the person that you want to be, not the person that maybe people thought you were in high school." Tacey's comments indicated that she believes she had already developed an identity prior to coming to college, but college helped expose it. Taylor's comments indicated more of a change in her identity due to being in college, a breaking out or discard of one's past personality traits.

Another common reflection was how much participants had grown in their understanding and appreciation of diversity and different viewpoints. Venus and Tacey were the most extreme among the participants, coming from homogeneous environments prior to coming to college. This development can be applied to the fifth vector, developing mature interpersonal relationships, in which students gain an appreciation for those who are different from them (Chickering \& Reisser, 1993). Tacey explained that her worldview had been expanded due to living on campus and learning about other lifestyles in her classes such as sociology. Similarly, Venus stated that prior to coming to campus, she was quite uncomfortable around non-Latinos. After having interactions with those who are racially or culturally different, she saw people for who they were and not what they were. She also had several friends from different racial and cultural backgrounds. The institution helped her develop these relationships through orientation, student organizations, and campus housing.

The participants were vocal about how they had developed purpose and career ambitions. All participants had a fairly concrete idea of what they wanted to be: actor, international occupational therapist, FBI agent, community organizer, dentist, and online music entrepreneur. This finding was somewhat surprising given that this vector is at the end of the spectrum and usually not achieved until the end of one's college career (Chickering \& Reisser, 1993). However, combined with recent research about this generation of college students, it does follow that the participants would be in tune with their future careers. They are described as idealistic, career focused, and committed to changing the world (Cawthon \& Miller, 2003). In line with the research, Venus talked about her first year in the context of a worldview, stating, "[Freshman year] was a lot of fun, good experiences that changed my life, made me learn a lot about myself and about the people around, like...the world...there's so much out there." Venus was also committed to changing her community for the better. Tacey knew that she wanted to be an occupational therapist since she was young; she commented, "I want to help everybody! I want to change the world. That's my goal—change the world." Taylor shared this global view: "My favorite thing [about] coming to college is meeting all these new people and there are so many people in the world and I want to meet all of them!"

Having an internal locus of control means being self directed and feeling in control of one's own fate (Pascarella, Edison, Hagedorn, Nora, \& Terenzini, 1996.) Those who are more externally focused believe their lives are affected by fate or destiny. A topic related to internal locus of control is coping behaviors and how they are employed. Eaton and Bean (1995) researched coping strategies among college students. They investigated the methods students used to cope with difficult situations, and found two strategies: approach and avoidance. Approach behaviors were positively correlated to achieving academic and social integration, therefore leading to persistence. Many of the 
participants in this study cited examples of internal locus of control, external locus of control, and coping behaviors.

The participants described behaviors that would fall under an internal locus of control framework. All of the students illustrated having personal determination to be successful in college. They described this determination as "trudging through the mud," "sticking it out," and "never giving up." Collectively the participants had overcome large obstacles to persist through to their sophomore year. Some of the challenges were surviving in a freshman residence hall with a high crime rate; overcoming a disability and maintaining a 3.93 grade point average; failing math but persevering due to help from teachers, tutors, and parents; overcoming a strong accent and rising to the top of English classes; and having only one class in the first semester, failing it, and being motivated enough to continue at the institution. Two participants directly stated that they now felt in complete control of their own fate, citing friends and family as supporting their destiny.

A countertheme emerged from the dialogues about control over one's destiny. Many students cited fate and God as having something to do with their success at the institution. God or spirituality was cited twice, both in positive ways. One participant prayed about being able to survive, and the other stated that if God would have wanted her to leave, she would have not survived. But she did survive, indicating it was God's plan for her to succeed. Other participants cited fate as having brought them to SJSU, but one of the participants felt now it was up to her to succeed. In some cases, comments regarding internal locus of control and more externally focused concepts like fate and destiny came from the same participants. At best, the participants seem to be struggling with the notion of who controlled their destiny.

\section{Research Question \#3: What recommendations do current students have for the institution and for future freshmen about promoting and achieving freshman success?}

The participants in this study had several recommendations for future freshmen. They reported that living on campus helped them to be successful in making friends, feeling comfortable, and connecting to the institution. They felt their involvement led to a sense of belonging and commitment. Four participants expressed the importance of getting to know professors, probably due to their positive experiences with certain faculty on campus. Finally, all participants represented a rare display of personal determination, and encouraged future freshmen to exercise personal determination. Therefore, the following are recommendations for future freshman about how to be successful: (a) live on campus to meet people, connect with resources, and expand your horizons; (b) get involved and connect to the campus; (c) get to know your professors and go to class; and (d) stay focused and determined.

The participants also had several recommendations for the institution including (a) consider many recommendations for orientation; (b) require second-semester advising for freshmen; (c) offer more programming and services to support the success of freshmen; (d) require freshmen to live on campus, but make it more affordable; (e) better connect students who live on campus to school spirit and athletics; and 
(f) illustrate to students the value of connecting to professors, recognizing that not all students place equal value on such relationships.

The participants had several recommendations for orientation, with many of the recommendations coming from one participant who experienced a difficult transition. The resource fair was perceived as overwhelming and perhaps not effective in terms of providing materials to students. A possible alternative that was offered was to invite all the resource fair representatives to speak to all students at orientation. The practical applications of this approach, however, would be difficult to implement due to the number of representatives involved. One participant remarked that she did not like being separated from her parents at orientation. One of the main goals of many orientation programs, however, is to help students become more independent and develop new relationships with parents. Separating students from parents at orientation is done intentionally to signal to students that they need to be responsible for themselves during college. Perhaps more could be done to help illustrate the reasoning for the separation of students and parents during orientation. There were also reflections on the need to make advising more developmental during orientation, and to require second-semester advising for freshmen. Tacey recommended second-semester advising because she felt like there was a big drop-off in support for freshmen. Ralphie's experiences also argue for requiring second-semester advising for freshmen.

There is also a need for the institution to make clear the value of attending precollege programs such as the Admitted Student Reception, orientation, and Welcome Week. These programs help freshmen connect to other students, faculty, and staff; obtain advising and course registration; get connected to resources; become comfortable and confident; validate one's choice of institution; and increase institutional commitment, to name a few. Although orientation is mandatory, there are still some students, like Ralphie, who did not attend due to various circumstances. It is critical that the institution be more firm on its deadlines for admission and confirmation of attendance, and make sure that every potential new student understands that the university expects them to attend precollege programs.

Participants reflected on the need for more programming for freshmen. Several participants who lived on campus reported going home often on weekends in their first year because they perceived there was nothing to do, and that everybody else went home. Therefore a recommendation to the institution would be to offer additional programs that are based on socialization and hold these programs on the weekends and possibly in the residence halls. A related recommendation is to emphasize living on campus more during precollege programs, but offer it at a lower cost for the first year.

Participants in the study offered specific recommendations for programming including workshops or gatherings for freshmen to make friends; a class that teaches students how to prepare for college; a program that connects new students to current students such as a shadowing or mentoring program; and outreach conferences aimed at students and parents that are interested in applying to SJSU, particularly for immigrant and first generation families.

Participants noted that contact with professors was important, but two of the 
participants illustrated that not all students see value in this contact. It is, therefore, important for the institution to find ways to educate new students about how significant faculty contact is to their success. The institution could begin by involving faculty and staff in precollege programs in intentional, significant ways. So as to not infringe on faculty and staff workloads, the institution needs to compensate them for such participation. The institution's MUSE courses are aimed at involving faculty and staff in intentional ways, and incorporates upper class students who serve as peer mentors. The courses, however, perhaps do not go as far as participants wished in terms of a focus on transition and preparation for college.

\section{Summary of Findings}

The findings for this study were two-fold. In terms of the preenrollment phase, it is critical that students and their families experience programs and services that educate them about the transition to college, increase students' commitment to the institution, and help students develop realistic expectations for college. Several factors were found to contribute to college freshman persistence, including support for social and academic integration, academic engagement, fostering student development, and promoting internal locus of control.

The first and second dialogues with participants yielded many reflections on what it means and what it takes for college freshmen to be successful. Participants reflected on their experiences through the precollege transition process, during precollege programs, and throughout their first year on campus. Both successes and challenges were shared throughout the reflection process. Students relished sharing the positive contacts they had made on campus with faculty, staff, and friends. Some emotional discomfort also occurred during the dialogues, including feelings of hopelessness and sadness.

Participants also reported feeling pleased that they participated and grateful for having the opportunity to reflect so deeply on their experiences. One participant shared, "I'm really glad that you invited me to do this, I really learned about myself... and about the people around me, and didn't realize about all that stuff until now...It was a really good experience, it opened my eyes, made me see what's out there, and I guess also find out about myself, and who I am." Many participants also reflected on their career path and purpose in life. All participants shared at least a general idea of where they were headed, with three of them knowing exactly what they wanted to do upon graduation. Each participant shared unique experiences during the precollege phase through their freshman year. These experiences were based on several elements including preenrollment factors such as individual attributes and preparation for college, perception of university programs and services, and the support systems that were formed. Although these experiences reflected unique reflections of participants, there were some common emerging themes that informed this study, as previously described. 


\section{Summary, Conclusions, and Recommendations}

Several conclusions can be drawn from the findings of this study. Preenrollment programs must be viewed as critical to student success, and should be mandatory and carried out utilizing current students who are trained in issues of transition. The placement test process is difficult for new students to navigate, and should be reviewed with an eye toward change. A freshman seminar course should also be required and must contain elements of transition in the curriculum. More programs are needed throughout the first year to help students develop social support networks. This study also found that parents are a positive source of support, and that the institution should work to provide parents with an orientation program and transitional support.

Students reported that they experienced growth and development in significant ways during their freshman year. They developed competence and negotiated new experiences that informed their personal belief systems. They learned how to forge new relationships with others and in the process learned about diversity. Although the participants had great cultural experiences, they struggled somewhat to articulate how these experiences informed their personal beliefs, and what the benefits were from these experiences. They began to explore and develop their identity as a result of interacting with their new environment. Participants also developed a sense of purpose and focus toward an occupation.

It is the hope of the researcher that this study may serve to empower future generations of college freshmen by offering recommendations from current students who successfully completed the freshman year. Through dialogue, the voice of students might have been illuminated, adding personal experiences to the rationale for why institutions should provide programs and services to freshmen that promote their success. The student participants were also empowered through reflection and meaningful dialogue about their experiences, and the knowledge that their recommendations will be brought forward to key administrators on campus.

\section{References}

American College Testing Program. (2001). More first-year college students return for second year; fewer students graduate in five years. ACT Newsroom, April 26, 2001. Retrieved on May 7, 2005, from www.act.org/news/releases/2001/04-26-01.html Astin, A. W. (1975). Preventing students from dropping out. San Francisco: Jossey-Bass. Astin, A. W. (1984). Student involvement: A developmental theory for higher education. Journal of College Student Personnel, 25, 297-308.

Astin, A. W. (1993). What matters in college: Four critical years revisited. San Francisco: Jossey-Bass.

Astin, A. W. (1996). Involvement in learning revisited: Lessons we have learned. Journal of College Student Development, 37, 123-134. 
Astin, A. W. (1997). How "good" is your institution's retention rate? Research in Higher Education, 38, 647-658.

Austin, D. (2003). The role of family influence on student success. In J. A. Ward-Roof \& C. Hatch (Eds.), Designing successful transitions: A guide for orientating students to college (Monograph No. 13, 2nd ed.) (pp. 137-163). Columbia, SC: National Resource Center for the Freshman Year Experience and Students in Transition, University of South Carolina.

Banning, J. H. (1989). Impact of college environments on freshman students. In M. L. Upcraft \& J. N. Gardner (Eds.), The freshman year experience: Helping students survive and succeed in college (pp. 53-62). San Francisco: Jossey-Bass.

Belenky, M. F., Clinchy, B. M., Goldberger, N. R., \& Tarule, J. M. (1986). Women's ways of knowing: The development of self, voice, and mind. New York: Basic Books.

Berger, J. B., \& Milem, J. F. (1999). The role of student involvement and perceptions of integration in a causal model of student persistence. Research in Higher Education, 40, 641-664.

Burd, S. (2004). Colleges permit too many needy students to drop out, says report on graduation rates. Retrieved on September 13, 2006, from http://chronicle.com/ weekly/v50/i39/39a01902.htm

Cawthon, T. W., \& Miller, M. (2003). Today's students and their impact on orientation and first-year programs. In J. A. Ward-Roof \& C. Hatch (Eds.), Designing successful transitions: A guide for orientating students to college (Monograph No. 13, 2nd ed.) (pp. 1-13). Columbia, SC: National Resource Center for the Freshman Year Experience and Students in Transition, University of South Carolina.

Chickering, A. W., \& Reisser, L. (1993). Education and identity (2nd ed.). San Francisco: Jossey-Bass.

Cohen, R. D. (1985). From in loco parentis to auxilio parentum. In R. D. Cohen (Ed.), Working with the parents of college students. (New Directions for Student Services No. 32) (pp. 3-14). San Francisco: Jossey-Bass.

Devlin, A. S. (1996). Survival skills training during freshman orientation: Its role in college adjustment. Journal of College Student Development, 37, 324-334.

Eaton, S. B., \& Bean, J. P. (1995). An approach/avoidance behavioral model of college student attrition. Research in Higher Education, 36, 617-645.

Fidler, P. P., \& Hunter, M. S. (1989). How seminars enhance students' success. In M. L. Upcraft \& J. N. Gardner (Eds.), The freshman year experience: Helping students survive and succeed in college (pp. 216-237). San Francisco: Jossey-Bass.

Freire, P. (1993). Pedagogy of the oppressed. New York: Garland Publishing, Inc.

Gardner, J. (1986). Student affairs and academic affairs: Bridging the gap. Carolina View, 2, 46-49.

Gardner, J. N., \& Hansen, D. A. (1993). Perspectives on the future of orientation. In M. L. Upcraft (Ed.), Designing successful transitions: A guide for orientating students to college (Monograph No. 13, pp.183-194). Columbia, SC: National Resource Center for the Freshman Year Experience, University of South Carolina.

Greenlaw, H. S., Anliker, M. E., \& Barker, S. J. (1997). Orientation: A student affairs or academic affairs function? NASPA Journal, 34, 303-313. 
Hickok, E. (2006). Higher education needs reform, too. Chronicle of Higher Education, 52(27), B48. Retrieved on September 13, 2006, from http://chronicle.com/weekly/ v52/i27/27b04801.htm

Howe, N. \& Strauss, W. (2000). Millennials rising. New York: Random House.

Hunter, M. S., Skipper, T. L., \& Linder, C. W. (2003). The first-year seminar: Continuing support for new student transitions. In J. A. Ward-Roof \& C. Hatch (Eds.), Designing successful transitions: A guide for orientating students to college (Monograph No. 13, 2nd ed.) (pp. 109-123). Columbia, SC: National Resource Center for the Freshman Year Experience and Students in Transition, University of South Carolina.

Jewler, A. J. (1989). Elements of an effective seminar. In M. L. Upcraft \& J. N. Gardner (Eds.), The freshman year experience: Helping students survive and succeed in college (pp. 198-215). San Francisco: Jossey-Bass.

Johnson, D. B. (2002). Student persistence: A study of student preenrollment factors and freshman to sophomore student persistence at a public university. Unpublished doctoral dissertation, The University of Alabama.

Kennedy, G. J., Gordon, R. L., \& Gordon, V. N. (1995). Changes in social and academic integration in freshmen of high and average ability: Implications for retention. NACADA Journal, 15 (2), 9-19.

Kieffer, C (1981). Doing “dialogic retrospection”: Approaching empowerment through participatory research. Paper presented at the International Meeting of the Society for Applied Anthropology, University of Edinburgh, Scotland.

Levitz, R., \& Noel, L. (1989). Connecting students to institutions: Keys to retention and success. In M. L. Upcraft \& J. N. Gardner (Eds.), The freshman year experience: Helping students survive and succeed in college. (pp. 65-81). San Francisco: JosseyBass.

Lewallen, W. (1993). The impact of being undecided on college student persistence. Journal of College Student Development, 34, 103-112.

Maguire, P. (1987). Doing participatory research: A feminist approach. Amherst, MA: The Center for International Education, University of Massachusetts.

Milem, J. F., \& Berger, J. B. (1997). A modified model of college student persistence: Exploring the relationship between Astin's theory of involvement and Tinto's theory of student departure. Journal of College Student Development, 38, 387-400.

Mullendore, R. H. (1998). Orientation as a component of institutional retention efforts. In R. H. Mullendore (Ed.), Orientation Planning Manual (pp. 1-7). Bloomington, IN: National Orientation Director's Association.

Mullendore, R. H., \& Abraham, J. (1993). Organization and administration of orientation programs. In M. L. Upcraft (Ed.), Designing successful transitions: A guide for orientating students to college (Monograph No. 13, pp. 61-77). Columbia, SC: National Resource Center for the Freshman Year Experience, University of South Carolina.

Murray, N. (1997). Welcome to the future: The millennial generation. Journal of Career Planning and Employment, 57 (3), 36-42. 
Park, P. (1993). What is participatory research? In P. Park, M. Brydon-Miller, B. Hall, \& T. Jackson (Eds.), Voices of change: Participatory research in the United States and Canada (pp. 1-19). Westport, CT: Bergin \& Garvey.

Pascarella, E. T., Edison, M., Hagedorn, L. S., Nora, A., \& Terenzini, P. (1996). Influences on students' internal locus of attribution for academic success in the first year of college. Research in Higher Education, 37, 731-755.

Perigo, D. J., \& Upcraft, M. L. (1989). Orientation programs. In M. L. Upcraft \& J. N. Gardner (Eds.), The freshman year experience: Helping students survive and succeed in college (pp. 82-94). San Francisco: Jossey-Bass.

Rendón, L. I. (1992). From the barrio to the academy: Revelations of a Mexican American "scholarship girl." In L. S. Zwerling \& H. B. London (Eds.), FirstGeneration Students: Confronting the Cultural Issues (pp. 55-64). New Directions for Community Colleges, No. 80. San Francisco: Jossey-Bass.

Sanders, L., \& Burton, J. D. (1996). From retention to satisfaction: New outcomes for assessing the freshman experience. Research in Higher Education, 37, 555-567.

Smith, B. F., \& Brackin, R. (1993). Components of a comprehensive orientation program. In M. L. Upcraft (Ed.), Designing successful transitions: A guide for orienting students to college (Monograph No. 13, pp. 35-48). Columbia, SC: National Resource Center for the Freshman Year Experience, University of South Carolina.

Strage, A. A. (1999). Social and academic integration and college success: Similarities and differences as a function of ethnicity and family educational background. College Student Journal, 33, 198-203.

Strumpf, G., \& Sharer, G. (1993). Trends and issues in orientation programs. In M. L. Upcraft (Ed.), Designing successful transitions: A guide for orientating students to college (Monograph No. 13, pp. 27-34). Columbia, SC: National Resource Center for the Freshman Year Experience, University of South Carolina.

Terenzini, P. T., Springer, L., Yaeger, P. M., Pascarella, E. T., \& Nora, A. (1996). First generation college students: Characteristics, experiences, and cognitive development. Research in Higher Education, 37 (1), 1-21.

Frances, C. (1998). Higher education: Enrollment trends and staffing needs. Research dialogues, 55. Retrieved on May 5, 2005, from http://www.tiaa-crefinstitute .org/research/dialogue/docs/55.pdf

Tinto, V. (1975). Dropout from higher education: A theoretical synthesis of recent research. Review of Educational Research, 45, 89-125.

Tinto, V. (1987). Leaving college: Rethinking the causes and cures of student attrition. Chicago: University of Chicago Press.

Tinto, V. (1993). Leaving college: Rethinking the causes and cures of student attrition (2nd ed.). Chicago: The University of Chicago Press.

Tinto, V. (1997). Classrooms as communities: Exploring the educational character of student persistence. Journal of Higher Education, 68, 599-623.

Upcraft, M. L. (1989). Residence halls and campus activities. In M. L. Upcraft \& J. N. Gardner (Eds.), The freshman year experience: Helping students survive and succeed in college (pp. 151-153). San Francisco: Jossey-Bass. 
Upcraft, M. L. (1993). Orienting today's students. In M. L. Upcraft (Ed.), Designing successful transitions: A guide for orientating students to college (Monograph No. 13, pp. 1-7). Columbia, SC: National Resource Center for the Freshman Year Experience, University of South Carolina.

Upcraft, M. L., \& Gardner, J. N. (1989a). A comprehensive approach to enhancing freshman success. In M. L. Upcraft \& J. N. Gardner (Eds.), The freshman year experience: Helping students survive and succeed in college (pp. 1-12). San Francisco: Jossey-Bass.

Upcraft, M. L., \& Gardner, J. N. (Eds.) (1989b). The freshman year experience: Helping students survive and succeed in college. San Francisco: Jossey-Bass.

Ward-Roof, J. A. (2003). A study of transfer students' grade point ratio, gender, ethnicity, number of hours transferred/academic status, college enrolled, transfer institution, and age. Unpublished doctoral dissertation, Clemson University.

Ward-Roof, J. A. \& Hatch, C. (2003). Designing successful transitions: A guide for orienting students to college, 2nd edition (Monograph No. 13). Columbia, SC: National Resource Center for the Freshman Year Experience, University of South Carolina.

Wilkie, C., \& Redondo, B. (1996). Predictors of academic success and failure of first-year college students. Journal of the Freshman Year Experience \& Students in Transition, 8 (2), 17-32.

Young, R. B., Backer, R., \& Rogers, G. (1989). The impact of early advising and scheduling on freshman success. Journal of College Student Development, 30 (4), 309-312. 


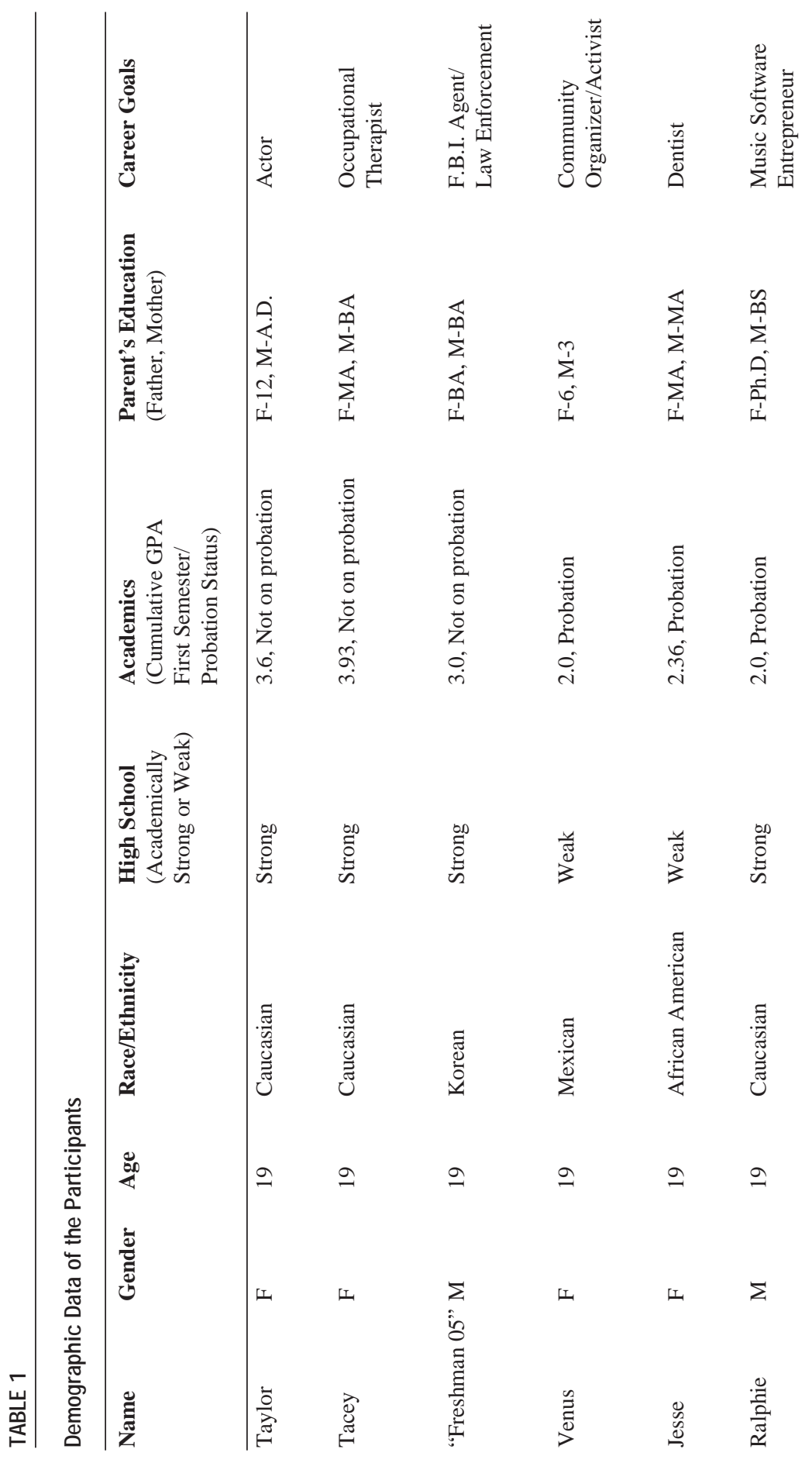

